\title{
Rancang Bangun Alat Ukur pH, Suhu dan Kelembaban Pada Media Tanam Jamur Tiram
}

\author{
Habibah Nurul Hidayah ${ }^{1}$, Anwar Mujadin ${ }^{2}$ \\ ${ }^{1,2}$ Program Studi Teknik Elektro, Fakultas Sains dan Teknologi, Universitas Al Azhar Indonesia, \\ Jalan Sisingamangaraja, Komplek Masjid Agung Al Azhar, Kebayoran Baru Jakarta Selatan 12110 \\ Penulis untuk Korespondensi/E-mail: amujadin@uai.ac.id
}

\begin{abstract}
Abstrak - Pada tulisan ini akan dibahas mengenai teknis pengukuran akurasi pH, suhu dan kelembaban yang menjadi bagian terpenting dalam menentukan kelayakan media jamur terutama pada tumbuh kembang jamur. Dalam penelitian ini telah dikembangkan sebuah divais elektronika untuk pengukuran media jamur terutama $\mathrm{pH}$, suhu dan kelembaban yang dirancang secara terintegrasi menggunakan mikrokontroler ATmega8. Prototipe dilengkapi dengan sensor pH TD60805 dan sensor suhu -kelembaban DHT22.
\end{abstract}

Kata Kunci - Prototipe Pengukur pH, Suhu dan Kelembaban Media Tanam Jamur. ATMega8, DHT22, dan Probe TD60805.

Abstract - This paper will discuss about the technical measurement of $\mathbf{p H}$ accuracy, temperature and inertia which become the most important part in determining the feasibility of mushroom media, especially on mushroom growth. This research has developed an electronic device for measurement of mushroom media especially $\mathrm{pH}$, temperature and humidity which is designed integrated using ATmega8 microcontroller. The prototype is equipped with a TD60805 pH sensor and a DHT22 temperature-humidity sensor.

Keywords - Prototype pH Measurement, Temperature and Humidity or Mushroom Growing Media, ATMega8, DHT22 and Probe TD60805

\section{PENDAHULUAN}

$P^{2}$ engetahuan tentang jamur yang masih kurang oleh petani menjadi masalah mendasar dalam budidaya jamur. Sedangkan salah satu bagian terpenting dalam budidaya jamur adalah media tanam. Media tanam merupakan komponen utama ketika bercocok tanam jamur sebagai tempat tumbuh dan kembangnya tanaman jamur. Media tanam akan menentukan baik buruknya pertumbuhan tanaman yang pada akhirnya mempengaruhi hasil produksi. Media tanam yang baik harus memiliki sifat-sifat fisik, kimia dan biologi yang sesuai dengan kebutuhan tanaman. Disamping itu perlu ditambahkan bahan-bahan lain seperti kapur (kalsium karbonat) sebagai sumber mineral jamur. Kadar media air diatur antara 50\%-60\% dengan menambah air bersih agar misellia jamur dapat tumbuh dan menyerap makanan dari media tanam dengan baik [1].

Tujuan yang hendak dicapai dalam penelitian ini adalah mempelajari karakteristik jamur tiram pada media tumbuh yang tepat sesuai dengan habitat hidupnya. Hasil dari penelitian ini adalah merancang prototipe untuk mengetahui apakah sistem berjalan dengan baik pada error yang lebih kecil $(<5 \%)$ serta dapat diterapkan pada komposisi jamur tiram yang tepat untuk meningkatkan kualitas dan kuantitas dari hasil produksi jamur tiram tersebut. Prototipe dirancang sedemikian mungkin berbentuk handheld agar mudah dibawa kemana-mana serta memiliki harga yang terjangkau. 


\section{IMPLEMENTASI ALAT}

Pada Gambar 1 diperlihatkan screenshot untuk rancang bangun rangkaian skematik elektronika.

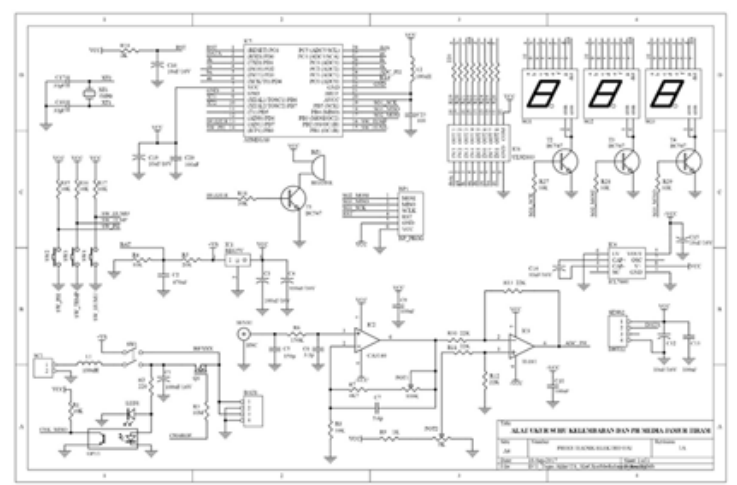

Gambar 1. Screenshot rangkaian skematik elektronika

Setelah mendapatkan rangkaian dan komponen elektronik yang dibutuhkan, maka selanjutnya melakukan validasi rangkain elektronika tersebut diatas sebuah project board.

Pada Gambar 2 diperlihatkan rangkaian elektronik pengukuran $\mathrm{pH}$, suhu dan kelembaban dalam sebuah project board.

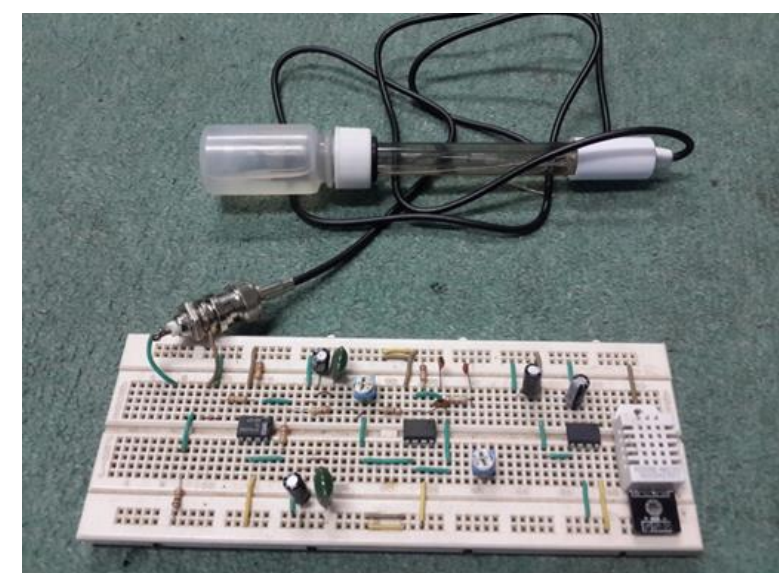

Gambar 2. Rangkaian Elektronik dalam sebuah project board

Karakterisasi pH meter dapat dilakukan bersamaan dengan percobaan diatas project board.

Pada Gambar 3 diperlihatkan rangkaian penguat $\mathrm{pH}$ meter berikut teknis tuning kalibrasi penguatan.

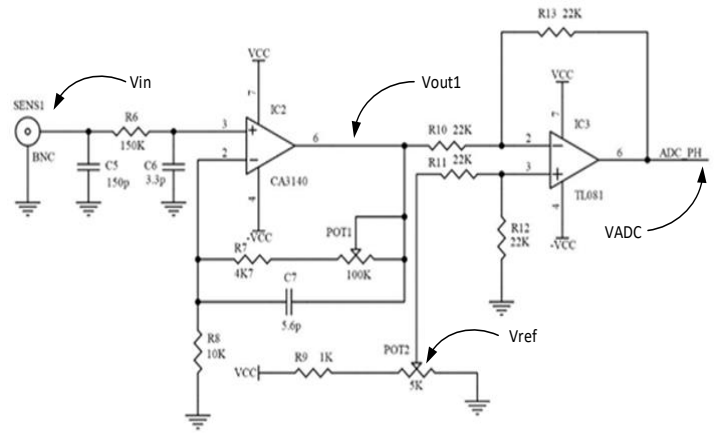

Gambar 3. Rangkaian penguat $\mathrm{pH}$ meter

Dari Gambar 3. terlihat probe TD60805 dihubungkan pada terminal SENS1 kemudian tegangan probe diamplifikasi menggunakan OpAmp IC2 dengan formulasi:

$$
\begin{gathered}
\mathrm{V}_{\text {OUT1 } 1}=-\left[\frac{\mathrm{POT} 1+\mathrm{R}_{7}}{\mathrm{R}_{8}}\right] \times \mathrm{V}_{\text {in }} \\
\mathrm{V}_{\text {OUT1 } 1=-}-\left[\frac{\mathrm{POT} 1+4.7 \mathrm{~K}}{10 \mathrm{~K}}\right] \times[-400 \mathrm{mV}-400 \mathrm{~V}] \\
\text { POT } 1+4.7 \mathrm{~K}=50 \mathrm{~K} \\
\text { POT } 1 \approx 45.3 \mathrm{~K}
\end{gathered}
$$

$\mathrm{POT} 1=$ diatur hingga penguatan -5 kali

Vref adalah tegangan referensi subtractor yang diatur sebesar $2.5 \mathrm{~V}$. Sedangkan nilai POT2 didapat dengan membagi tegangan sebesar:

$$
\begin{gathered}
\mathrm{V}_{\mathrm{REF}}=-\left[\frac{\mathrm{POT} 2}{\mathrm{POT} 2+\mathrm{R}_{8}}\right] \times \mathrm{V}_{\mathrm{cc}} \\
2.5 \mathrm{~V}=-\left[\frac{\mathrm{POT} 2}{\mathrm{POT} 2+1 \mathrm{~K}}\right] \times 5 \mathrm{~V} \\
\text { dari } \frac{\mathrm{POT} 2}{\text { POT } 2+1 \mathrm{~K}}=\frac{1}{2} \\
\text { sehingga POT2 }=1 \mathrm{~K}
\end{gathered}
$$

Vref dapat diatur, untuk menentukan kepresisian pembacaan ambang ADC mikrokontroler. Kenyataannya tiap probe $\mathrm{pH}$ memiliki karakter sesuai dengan pabrikan maka penentuan nilai Vref perlu diatur secara variasi sesuai dengan karakter dari probe.

VADC adalah nilai keluaran penguatan $\mathrm{pH}$ probe yang diformulasikan sebagai berikut:

$$
\begin{gathered}
\mathrm{v}_{\mathrm{ADC}}=\mathrm{v}_{\mathrm{REF}}-\mathrm{V}_{\text {OUT1 }} \\
\mathrm{V}_{\mathrm{ADC}}=2.5 \mathrm{~V}-\mathrm{V}_{\text {OUT}} 1
\end{gathered}
$$

Agar nilai pembacaan $\mathrm{ADC}$ probe $\mathrm{pH}$ didapat antara nilai $0-5 \mathrm{~V}$, maka diperoleh tegangan $\mathrm{Vref}=2.5 \mathrm{~V}$. 
Pada Gambar 4 diperlihatkan divais (prototipe) hasil penelitian.

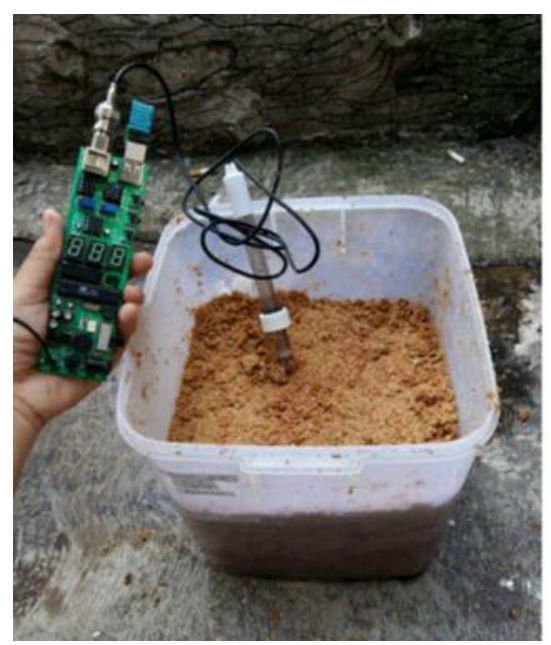

Gambar 4. Prototipe hasil penelitian

\section{METODE PENELITIAN}

Pengumpulan data sepenuhnya diperoleh berdasarkan hasil eksperimen baik hardware maupun software. Dengan urutan pengambilan data sebagai berikut:

a. Karakterisasi tranduser $\mathrm{pH}$ (tipe TD60805), dan modul suhu serta kelembaban (tipe DHT22).

b. Pengujian rangkaian penguat $\mathrm{pH}$ meter. Pengujian penguatan OP-AMP pada satu tegangan referensi.

c. Pengukuran tingkat presisi dan akurasi antara sensor dengan alat ukur (kalibrator).

d. Pengujian prototipe pada real objek ukur (media tanam) jamur tiram.

e. Kalibrasi pengukuran suhu dan kelembaban menggunakan kalibrator Constant HT100 dan sensor DHT22 dengan cara menyamakan nilai output keduanya melalui tuning pada software, yang kemudian dikalibrasikan pada ruangan terbuka.

f. Kalibrasi antara $\mathrm{pH} 7$ ( $\mathrm{pH}$ normal) dan cairan buffer 7 menggunakan kalibrator (PH-009) dan sensor (TD60805) pada ruangan terbuka.

g. Melakukan kalibrasi pengukuran suhu dan kelembaban pada suhu suatu ruangan antara $21^{\circ} \mathrm{C}$ sampai $30^{\circ} \mathrm{C}$ menggunakan sensor DHT22 dengan kalibrator pembanding type HT100 merek Constant. h. Melakukan kalibrasi $\mathrm{pH}$ antara prototipe dan kalibrator menggunakan cairan buffer pH 7 pada suhu ruangan tertutup.

i. Mencari nilai kesalahan relatif suhu dan kelembaban dari hasil implementasi pada media tanam jamur menggunakan variasi kuantitas berupa serbuk gergaji, kapur, bekatul dan air.

j. Mencari nilai kesalahan relatif $\mathrm{pH}$ dari hasil implementasi media tanam jamur dengan menggunakan variasi kuantitas yang sama dengan suhu dan kelembaban.

Sedangkan metode penelitian dibagi menjadi:

a. Pemilihan mikrokontroller.

b. Pencarian referensi sensor $\mathrm{pH}$, humidity dan suhu.

c. Pencarian referensi mekanisme kalibrasi prototipe.

\section{HASIL PENELITIAN}

Rancangan pinout diagram mikrokontroler dari sistem pengukuran $\mathrm{pH}$, suhu dan kelembaban diperlihatkan pada Gambar 5 di bawah ini.:

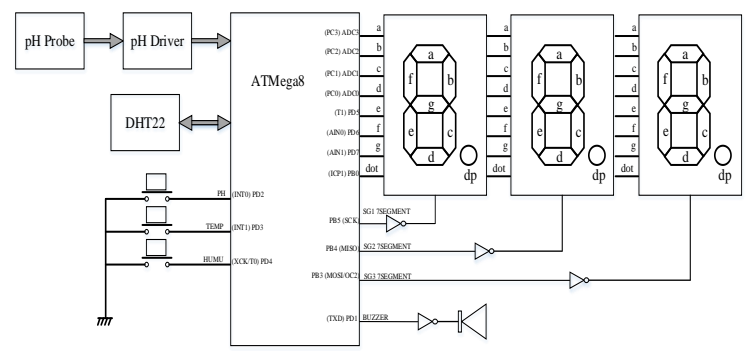

Gambar 5. Pinout diagram Mikrokontroler.

Sedangkan Gambar 6 diperlihatkan prototipe dari rancang bangun alat ukur $\mathrm{pH}$, suhu dan kelembaban dengan media tanam jamur tiram.

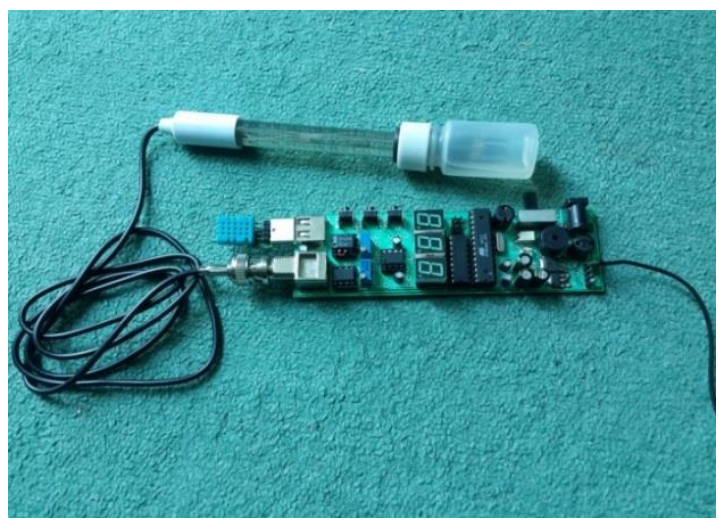

Gambar 6. prototipe dari rancang bangun alat ukur $\mathrm{pH}$, suhu dan kelembaban dengan media tanam jamur tiram 
Prototipe diujicobakan pada dua skema percobaan yaitu menggunakan cairan buffer (referensi) dan menggunakan media jamur sesungguhnya. Prototipe dikalibrasi menggunakan kalibrator (pembanding) HT100 merek Constant untuk penentuan nilai akurasi suhu dan kelembaban, sedangkan tipe $\mathrm{PH}-009$ (V.1) digunakan untuk kalibrasi $\mathrm{pH}$. Pengukuran $\mathrm{pH}$ dikalibrasi hanya pada suhu kamar $\left(25^{\circ} \mathrm{C}\right)$ karena prototipe memang diimplementasikan untuk media pada suhu kamar. Skema pengujian ini dilakukan untuk mengukur tingkat kepresisian dan keakuratan sensor (kelayakan).

Pada Tabel 1 diperlihatkan hasil ukur rangkaian penguat $\mathrm{pH}$ meter dengan media cairan buffer (bukan media jamur).

Table 1. Hasil pengukuran rangkaian penguat $\mathrm{pH}$ Meter denganMedia cairan buffer (bukan media jamur)

\begin{tabular}{ccccccc}
\hline $\begin{array}{c}\mathrm{pH} \\
\text { (slope) }\end{array}$ & $\begin{array}{c}\text { Out } \\
\text { Probe }\end{array}$ & $\begin{array}{c}\text { Amplifikasi } \\
(\mathrm{mV})\end{array}$ & $\begin{array}{c}\text { subtrator } \\
(\mathrm{mV})\end{array}$ & $\begin{array}{c}\text { Hasil } \\
\text { Hitung }(\mathrm{V})\end{array}$ & $\begin{array}{c}\text { Hasil } \\
\text { Ukur }(\mathrm{V})\end{array}$ & $\begin{array}{c}\text { Kesalahan } \\
\text { Relatif }(\%)\end{array}$ \\
\hline 1 & 342.84 & -1714.2 & 4214.4 & 4.2142 & 4.18 & 0.812 \\
2 & 285.7 & -1428.5 & 2928.5 & 3.9285 & 3.85 & 1.998 \\
3 & 228.56 & -1142.8 & 3642.8 & 3.6428 & 3.56 & 2.273 \\
4 & 171.42 & -857.1 & 3357.1 & 3.3571 & 3.29 & 1.999 \\
5 & 114.28 & -571.4 & 3071.4 & 3.0714 & 3.01 & 1.999 \\
6 & 57.14 & -285.7 & 2785.7 & 2.7857 & 2.69 & 3.435 \\
7 & 0 & 0 & 2500 & 2.5 & 2.5 & 0.000 \\
8 & -57.14 & 285.7 & 2214.3 & 2.2143 & 2.15 & 2.904 \\
9 & -114.28 & 571.4 & 1928.6 & 1.9286 & 1.88 & 2.520 \\
10 & -171.42 & 857.1 & 1642.9 & 1.6429 & 1.58 & 3.829 \\
11 & -228.56 & 1142.8 & 1357.2 & 1.3572 & 1.39 & 2.417 \\
12 & -285.7 & 1428.5 & 1071.5 & 1.0715 & 1.03 & 3.873 \\
\hline \multicolumn{7}{c}{ Kesalahan relatif (rata-rata) } \\
\hline \multicolumn{7}{c}{}
\end{tabular}

Dari Tabel 1 dapat disimpulkan bahwa nilai error terkecil berada di pengukuran $\mathrm{pH} 7$ sedangkan nilai error terbesar berada di $\mathrm{pH} 12$. Sedangkan nilai rata-rata dari hasil error yang didapat sebesar $2.338 \%$.

Grafik hasil pengukuran dan perhitungan pada penguat $\mathrm{pH}$ meter dengan media cairan buffer diperlihatkan pada Gambar 7 berikut:

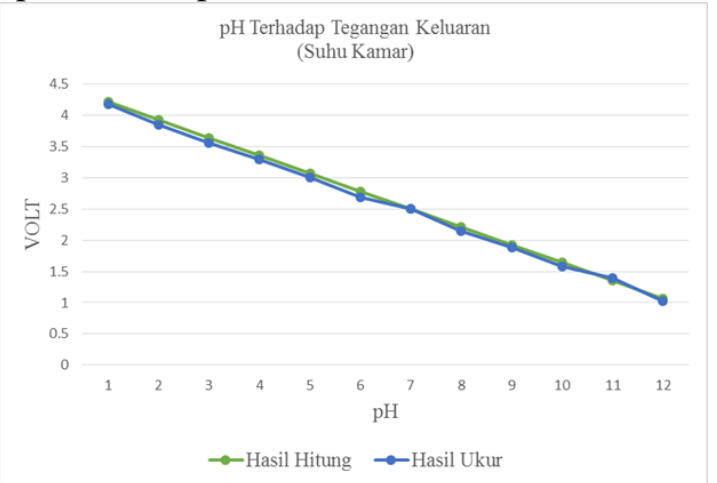

Gambar 7. Grafik hasil hitung dan hasil ukur menggunakan media cairan buffer
Pada Tabel 2 diperlihatkan hasil pengukuran suhu dan kelembaban sensor DHT 22 pada ruangan (tanpa media jamur) dengan pembanding kalibrator type HT100 merek Constant.

Tabel 2 Hasil ukur suhu dan kelembaban DHT22 dengan pembanding kalibrator HT100 merek Constant.

\begin{tabular}{|c|c|c|c|c|c|c|c|}
\hline \multirow{3}{*}{ No } & \multirow{3}{*}{$\begin{array}{c}\text { Suhu } \\
\text { Ruangan }\end{array}$} & \multirow{2}{*}{\multicolumn{2}{|c|}{$\begin{array}{c}\text { Kalibrator } \\
\text { HT100 }\end{array}$}} & \multirow{2}{*}{\multicolumn{2}{|c|}{\begin{tabular}{|c|} 
Prototype \\
DHT22 \\
\end{tabular}}} & \multirow{3}{*}{$\begin{array}{c}\text { Kesalahan } \\
\text { Relatif T } \\
(\%)\end{array}$} & \multirow{3}{*}{$\begin{array}{c}\text { Kesalahan } \\
\text { Relatif H } \\
(\%)\end{array}$} \\
\hline & & & & & & & \\
\hline & & $\mathrm{T}$ & $\mathrm{H}$ & $\mathrm{T}$ & $\mathrm{H}$ & & \\
\hline 1 & 21 & 21 & 88 & 21.2 & 87.2 & 0.952 & 0.909 \\
\hline 2 & 22 & 22.1 & 85 & 22 & 85.5 & 0.452 & 0.588 \\
\hline 3 & 23 & 23 & 84.7 & 23.2 & 83.7 & 0.87 & 1.181 \\
\hline 4 & 24 & 24.2 & 81.6 & 24.4 & 82.1 & 0.826 & 0.613 \\
\hline 5 & 25 & 25.1 & 79.9 & 25.2 & 80.3 & 0.398 & 0.501 \\
\hline 6 & 26 & 26.3 & 77.3 & 26.3 & 78.1 & 0.766 & 1.035 \\
\hline 7 & 27 & 27.2 & 75.1 & 27.2 & 76.2 & 0.741 & 1.465 \\
\hline 8 & 28 & 28 & 73.2 & 28 & 74.3 & 0.709 & 1.503 \\
\hline 9 & 29 & 29.3 & 71.7 & 29.3 & 72.9 & 0.687 & 1.674 \\
\hline 10 & 30 & 30.2 & 70.2 & 30.2 & 71.6 & 0.667 & 1.994 \\
\hline
\end{tabular}

Dari hasil pengamatan pada Tabel 1 dan Tabel 2 terlihat bahwa kesalahan relatif pembacaan suhu sebesar $0,398 \%$ dan kesalahan relatif kelembaban sebesar $0,501 \%$ diuji pada suhu kamar ( suhu ruangan $25^{\circ} \mathrm{C}$ ) pada media jamur ukuran baglog volume $0.008 \mathrm{~m} 3$.

Pada Tabel 3 diperlihatkan pengujian prototipe pengukuran $\mathrm{pH}$ pada variasi kuantitas serbuk gergaji, kapur, bekatul dan air dengan total volume $0.008 \mathrm{~m}^{3}$ menggunakan kalibrator.

Tabel 3. Hasil pengujian prototipe pengukuran $\mathrm{pH}$ terhadap variasi kuantitas serbuk gergaji, kapur, bekatul dan air menggunakan kalibrator.

\begin{tabular}{cccccccc}
\hline & \multicolumn{3}{c}{ Media } & \multicolumn{3}{c}{ Kalibrator } & \multicolumn{2}{c}{ Prototype Kesalahan } \\
\cline { 2 - 8 } No & Serbuk & Kapur & Bekatul & Air & Type PH-009(1) & TD60805 & Relatif \\
\cline { 2 - 8 } & Gergaji (gr) & (gr) & (gr) & $\underline{\text { (ml) }}$ & pH & pH & $(\%)$ \\
\hline 1 & 140 & 10 & 200 & 700 & 4.9 & 5.1 & 4.082 \\
2 & 150 & 12 & 180 & 900 & 5.3 & 5.5 & 3.774 \\
3 & 160 & 14 & 160 & 1100 & 5.9 & 6.1 & 3.39 \\
4 & 170 & 16 & 140 & 1300 & 6.4 & 6.5 & 1.562 \\
$\mathbf{5}$ & $\mathbf{1 8 0}$ & $\mathbf{1 8}$ & $\mathbf{1 2 0}$ & $\mathbf{1 5 0 0}$ & $\mathbf{6 . 7}$ & $\mathbf{6 . 8}$ & $\mathbf{1 . 4 9 3}$ \\
6 & 190 & 20 & 100 & 1700 & 7.1 & 7.3 & 2.817 \\
7 & 200 & 22 & 80 & 1900 & 7.8 & 8.1 & 3.846 \\
8 & 210 & 24 & 60 & 2100 & 8.2 & 8.4 & 2.439 \\
\hline
\end{tabular}

Dari Tabel 3. Variasi media pada 180 gr serbuk gergaji, 18 gr kapur, 120 gr bekatul dan $1500 \mathrm{ml}$ air memiliki nilai kesalahan relatif $\mathrm{pH}$ yang lebih kecil sebesar $1.493 \%$ antara pengukuran kalibrator dan real prototype.

Pada Tabel 4 diperlihatkan pengujian prototipe pengukuran $\mathrm{pH}$ pada variasi kuantitas serbuk gergaji, kapur, bekatul dan air dengan total volume $0.008 \mathrm{~m}^{3}$ tanpa media dan dengan media. 
Tabel 4 .Hasil pengujian prototipe pengukuran suhu dan kelembaban terhadap variasi kuantitas serbuk gergaji, kapur, bekatul dan air dengan media dan tanpa media.

\begin{tabular}{|c|c|c|c|c|c|c|c|c|c|c|}
\hline \multirow{3}{*}{ No } & \multicolumn{4}{|c|}{ Media } & \multirow{2}{*}{\multicolumn{2}{|c|}{$\begin{array}{c}\text { Ruang Terbuka } \\
\text { Tanpa Media }\end{array}$}} & \multirow{2}{*}{\multicolumn{2}{|c|}{$\begin{array}{c}\text { Prototype } \\
\text { DHT22 }\end{array}$}} & \multicolumn{2}{|c|}{ Kesalahan Kesalaha } \\
\hline & Serbuk & Kapur & Bekatul & Air & & & & & Relatif $\mathrm{T}$ & Relatif $\mathrm{H}$ \\
\hline & Gergaii (gr) & (gr) & (gr) & $(\mathrm{ml})$ & $T$ & H & $T$ & $\mathrm{H}$ & $(\%)$ & $(\%)$ \\
\hline 1 & 140 & 10 & 200 & 700 & 21 & 88 & 21.3 & 88.4 & 1.429 & 0.455 \\
\hline 2 & 150 & 12 & 180 & 900 & 22.1 & 85 & 22.2 & 85.2 & 0.452 & 0.235 \\
\hline 3 & 160 & 14 & 160 & 1100 & 23 & 84.7 & 23.4 & 84.5 & 1.739 & 0.236 \\
\hline 4 & 170 & 16 & 140 & 1300 & 24.2 & 81.6 & 24.3 & 81.1 & 0.413 & 0.613 \\
\hline 5 & 180 & 18 & 120 & 1500 & 25.1 & 79.9 & 25.2 & 80 & 0.398 & 0.125 \\
\hline 6 & 190 & 20 & 100 & 1700 & 26.1 & 77.3 & 26.3 & 78.3 & 0.766 & 1.294 \\
\hline 7 & 200 & 22 & 80 & 1900 & 27 & 75.1 & 27.5 & 75.9 & 1.852 & 1.065 \\
\hline 8 & 210 & 24 & 60 & 2100 & 28.2 & 73.2 & 28 & 73.6 & 0.709 & 0.546 \\
\hline
\end{tabular}

Dari Tabel 4 diperlihatkan komposisi terbaik pada komposisi variasi berturut turut serbuk gergaji, kapur, bekatul dan air sebesar 180gr,18gr 120gr dan 1500ml. Hasil pengukuran menunjukan optimal untuk media jamur tiram [1], dengan kesalahan relatif suhu sebesar $0.398 \%$ dan kesalahan relatif kelembaban sebesar $0.125 \%$.

\section{KESIMPULAN}

Dari hasil pengamatan dan pengujian dapat disimpulkan antara lain:

a. Ditunjukan bahwa pengujian antara rangkaian $\mathrm{pH}$ prototipe dengan $\mathrm{pH}$ kalibrator tipe $\mathrm{pH}-009$ yang diujikan pada rentang $\mathrm{pH}$ buffer 6-9, memiliki kesalahan relatif rata-rata sebesar $2,338 \%$. Kesalahan relatif ini disebabkan karena karakteristik dari probe sensor $\mathrm{pH}$. Responsif bulb sensor pada $\mathrm{pH}$ meter ditentukan oleh waktu tunda saat pengumpulan ion $\mathrm{H}+$ (asam) dan ion OH- (basa).

b. Pada variasi kuantitas serbuk gergaji, kapur, bekatul dan air berturut-turut sebesar 180 gr, 18 gr, 120 gr dan 1500 ml medekati media tanam optimal jamur tiram.

c. Kesalahan relatif menjadi bagian terpenting untuk menentukan tingkat kepersisian dan keakurasian prototipe hasil penelitian. Karakterisasi sensor menggunakan valid kalibrator sangat penting untuk diperhatikan.

\section{DAFTAR PUSTAKA}

[1] L.Mufarrihah, "Pengaruh Penambahan Bekatul dan Ampas Tahu Pada Media Terhadap Pertumbuhan dan Produksi Jamur Tiram Putih", Universitas Islam Negri Malang, Malang, 2009.

[2] P.Vany'sek,"The Glass pH Electrode", The Electrochemical Society Interface, 2004.

[3] G.McMillan \& D.Joseph, "Adventures in pH Control", the 2012 Emerson Exchange in Anaheim, California USA, 2012.

[4] R.E.Wahyono, "Rancang Bangun Sistem Kendali Otomatis Temperatur dan Kelembaban Kumbung Jamur Tiram Berbasis Mikrokontroler", Universitas Lampung, Bandarlampung, 2016.

[5] I.Purnama, "Rancang Bangun Alat Pengukuran Laju Kendaraan Berbasis Mikrokontroler ATMEGA 8", perpustakaan UNIKOM, 2011

[6] D.M. Sembiring, "Simulasi Rancang Bangun Alat Hitung Sepeda Motor Memanfaatkan Inframerah Sebagai Input Pada Pintu Gerbang", Universitas Sumatera Utara, Medan, 2014

[7] H.Nurjaya, "Rancang Bangun Prototipe Pengendalian Kelembaban Pada Kumbung Jamur Tiram Dengan Kabut Buatan Berbasis Mikrokontroler Attini45", Universitas Al Azhar Indonesia, Jakarta, 2013.

[8] S.Y.Arto, "Visualisasi Pengaturan Suhu dan Kelembaban Udara Pada Media Ruang Tumbuh Jamur Dengan Program Visual Basic 6.0", Institut Pertanian Bogor, Bogor, 2006.

[9] S.Hadi \& F.Rakhmad, "Pengaturan Suhu dan Kelembaban Pada Miniatur Kumbung Jamur Tiram", Institut Teknologi Sepuluh Nopember, Surabaya, 2015.

[10] E.E.C.Ginting, "Alat Sistem Pengendali Suhu dan Kelembaban pada Inkubator Jamur", Universitas Sumatera Utara, Medan, 2016. 